\title{
Theory of Planned Behavior Predicts Graduation Intentions of Canadian and Israeli Postsecondary Students with and without Learning Disabilities/Attention Deficit Hyperactivity Disorder
}

\author{
Catherine S. Fichten ${ }^{1,2,3,4}$, Tali Heiman ${ }^{5}$, Mary Jorgensen ${ }^{2}$, Mai Nhu Nguyen ${ }^{2}$, Alice Havel ${ }^{2}$, Laura King ${ }^{6}$, Jillian \\ Budd $^{2} \&$ Rhonda Amsel ${ }^{7}$ \\ ${ }^{1}$ Department of Psychology, Dawson College, Montreal, Canada \\ ${ }^{2}$ Adaptech Research Network, Montreal, Canada \\ ${ }^{3}$ Department of Psychiatry, McGill University, Montreal, Canada \\ ${ }^{4}$ Department of Psychiatry, Jewish General Hospital, College, Montreal, Canada \\ ${ }^{5}$ Department of Education and Psychology, The Open University of Israel, Ra'anana, Israel \\ ${ }^{6}$ Département de langues, Cégep André-Laurendeau, Montreal, Canada \\ ${ }^{7}$ Department of Psychology, McGill University, Montreal, Canada \\ Correspondence: Catherine Fichten, Department of Psychology, Dawson College, Montreal, H3Z 1A4, Canada. Tel: \\ $1-514-931-8731$
}

Received: December 5, 2015

Accepted: December 30, $2015 \quad$ Online Published: January 12, 2016

doi:10.5430/ijhe.v5n1p208

URL: http://dx.doi.org/10.5430/ijhe.v5n1p208

\begin{abstract}
We tested the ability of Ajzen's Theory of Planned Behavior (TPB) model to predict intention to graduate among Canadian and Israeli students with and without a learning disability / attention deficit hyperactivity disorder (LD/ADHD). Results based on 1486 postsecondary students show that the model's predictors (i.e., attitude, subjective norms, perceived behavioral control related to graduation) predicted between $32 \%$ and 59\% of the variability in intention to graduate. Gender made a minor contribution to the prediction equation and age was unrelated. This suggests that our TPB measure, included in Table 1, is valid for diverse samples and countries. It can be used as a quick, inexpensive way to predict intention to graduate and, as shown by previous investigations, actual graduation rates. Thus, strengthening the three predictors may result in higher graduation rates.
\end{abstract}

Keywords: Theory of Planned Behavior, TPB, Canada, Israel, Graduation, Intention to graduate, College, University postsecondary, Learning disability, Attention deficit hyperactivity disorder

\section{Introduction}

\subsection{Why the Topic is Important}

Graduation from postsecondary education is important to all stakeholders, including students, colleges, universities, government, funders, parents, as well as society at large. In North America, including Canada, graduation rates have typically varied between 50\% and 65\% (Jorgensen et al., 2005; Shaienks, Gluszynski, \& Bayard, 2008; American College Testing Program, 2013), depending on the type of institution (junior and community college, university, public/private), location, program of study, and duration of follow-up. In Israel, according to the OECD reports (2012, 2013) $46 \%$ of residents had tertiary education (including universities and colleges), and the drop-out rate has been estimated at $30 \%$ (personal communication, Dec. 1, 2015).

What this means, in practical terms, is that thirty to fifty out of every 100 students currently enrolled will drop out - an outcome that is clearly undesirable. Thus, it is not surprising that postsecondary institutions are interested in ways of improving graduation rates and of measuring the likelihood of graduation among different populations of students. For example, in order to increase student retention, the Open University of Israel (OU) focused on 1,700 students defined as drop-outs, as they did not enroll in courses during the three preceding semesters. Therefore, the OU academic counseling center added a special unit designed to assist students in returning to their studies and completing an academic degree. Varieties of administrative and academic accommodations were presented to these students in order to encourage them to return to their studies and complete their degrees. It appears that from 1,494 students who 
were directly assisted, $10.4 \%$ of them have completed their studies and earned undergraduate degrees, $32.3 \%$ have returned to their studies, while others have either rejected the approach or could not be located (The Open University: The President Report, 2013, 2014).

The literature on predicting graduation, persistence from one year to the next, as well as intention to graduate from colleges and universities has been heavily influenced by the work of Bean (1982) and Tinto (1975). A large number of studies have examined pre-entry characteristics, such as parental education, age, gender, financial need, high school performance, school and student demographics such as full vs. part-time studies, academic and social integration, student contact with faculty, student engagement, as well as personality, psychosocial adjustment, and social support (Chen, 2012; Hudy, 2007; Jorgensen, Ferraro, Fichten, \& Havel, 2009; Heller \& Cassady, 2015; Luke, Redekop \& Burgin, 2015; National Center for Education Statistics, 2010; Strom \& Savage, 2014). Yet, in spite of strong interest and a vast literature, prediction of graduation, drop-out, and intention to graduate have a relatively poor track record, even when a large number of variables such as grades, gender, and survey results are included (e.g., Heller \& Cassady, 2015; Jorgensen et al., 2009; Jorgensen, Fichten, \& Havel, 2008; Luke, Redekop \& Burgin, 2015). To improve on the prediction we recently developed the Theory of Planned Behavior Postsecondary Graduation Questionnaire, a one page measure based on Ajzen's $(2002,2012)$ Theory of Planned Behavior (TPB).

\subsection{The Theory of Planned Behavior (TPB)}

The TPB is a general model to predict behavior which states that, "Intention is an indication of a person's readiness to perform a given behavior, and it is considered to be the immediate antecedent of behavior. The intention is based on attitude toward the behavior, subjective norm, and perceived behavioral control, with each predictor weighted for its importance in relation to the behavior and population of interest" (Ajzen, undated a). In the case of postsecondary students, the model states that graduation is influenced by intention to graduate, which is predicted by the following correlated variables: perceived behavioral control (i.e., ease or difficulty of performing the behavior - in our case graduation), subjective norms (i.e., perceived social/peer pressure from individuals important in the student's life), and attitude (i.e., positive or negative evaluation of graduation). Ajzen (1991, p. 182) used the model in Figure 1 to illustrate the TPB, which has been highly effective and influential in several domains (Armitage \& Conner, 2001). Moreover, the relationship between intention and actual behavior is reasonably robust (McEachan, Conner, Taylor, \& Lawton, 2011).

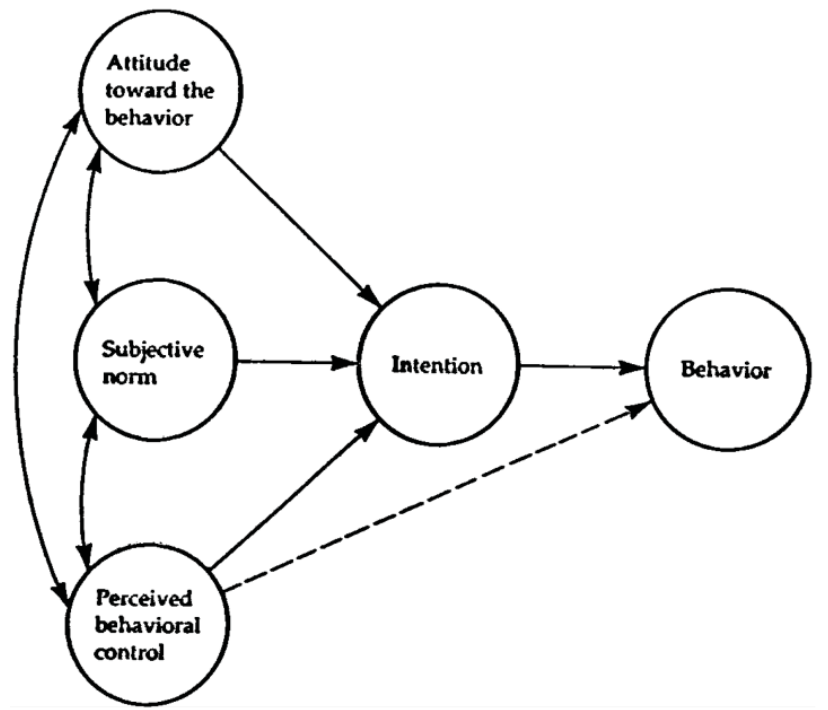

Figure 1. Theory of Planned Behavior (Ajzen, 1991, p. 182)

"Interventions designed to change behavior can be directed at one or more of its determinants: attitudes, subjective norms, or perceptions of behavioral control. Changes in these factors should produce changes in behavioral intentions and, given adequate control over the behavior, the new intentions should be carried out under appropriate circumstances." (Ajzen, undated b). Thus, if we can demonstrate that the components of the TPB model can predict intention to graduate, interventions by colleges and universities to strengthen one or more components may improve retention and graduation rates. 


\subsection{Graduation of Students with Disabilities}

Over $10 \%$ of higher education students in North American have a variety of disabilities such as a learning disability, visual impairment, and mobility impairment (Ministry of Training, Colleges \& Universities, 2012; Snyder \& Dillow, 2012). These students need to overcome unique barriers to pursue postsecondary education, including both human and technological accommodations; these include note takers and assistive technologies (Fichten, Asuncion, et al., 2012; Lang, et al., 2014). Thus, it is not surprising that there is substantial variability in reported graduation rates among samples of students with disabilities (Getzel \& Thoma, 2008; Jorgensen, Ferraro, Fichten, \& Havel, 2009; Jorgensen, et al., 2005; Lombardi, Murray, \& Gerdes, 2012; O'Neill, Markward, \& French, 2012; Wessel, Jones, Markle, \& Westfall, 2009). What seems clear is that students with disabilities take additional time to graduate.

\subsection{Learning disabilities (LD) and Attention Deficit and Hyperactivity Disorder (ADHD) in Postsecondary} Education

LD and ADHD are among the most common disabilities of students in higher education in North America (McCloy \& DeClou, 2013; NCES, 2011; Raue \& Lewis, 2011). ADHD and LD often co-occur (DuPaul, Gormley, \& Laracy, 2013). Therefore, research often classifies them as one group "LD and/or ADHD" (e.g., Parker \& Banerjee, 2007). Graduation rates of students with LD and ADHD typically lag behind their peers without disabilities (Advokat, Lane, \& Luo, 2011; Weyandt et al., 2013; Wagner et al., 2005).

\subsection{North American and Israeli Students with and without Specific Learning Disabilities and Attention Deficit} Disorder

The TPB has been used successfully to predict graduation and intention to graduate in various North American postsecondary samples (e.g., Thomas, 2014; Fichten, et al., 2014, 2015; Sutter, 2014). However, it has not been used for Israeli students, or for students attending an open university. Nor has it been used to examine intention to graduate among students with the most common disability among North American and Israeli students: students with specific learning disabilities and/or attention deficit disorder (LD/ADHD) (DuPaul, et al., 2013; McCloy \& DeClou, 2013; NCES, 2011). Therefore, our objective in the present investigation was to evaluate the efficacy of the TPB model to predict intention to graduate among students with and without LD/ADHD in Israel and Canada, especially because North American studies show that graduation rates of students with LD and ADHD lag behind their peers without disabilities (Wagner, Newman, Cameto, Garza, \& Levine., 2005; Weyandt et al., 2013). In Israel, students with LD/ADHD studying in higher education institutes are under-represented. In addition, they take longer to graduate and they often experience difficulties in the humanities, social sciences, and foreign languages compared to students without disabilities (Heiman \& Precel, 2003).

Israel and Canada are dissimilar in many ways that affect education, including language and alphabet. In addition, the postsecondary education systems differ. For example, in some parts of Canada, students matriculate after 11 years of school (variously called high school, secondary school); in Israel, this typically occurs after 12 years. In addition, students in some parts of Canada attend two compulsory years of junior college before enrolling in a three year university bachelor's program; in Israel, students register in a three-year bachelor program directly after matriculation. In addition, Israeli students typically enlist in the army shortly after high school graduation; in Canada, this is not the case. What the two countries do have in common is significant numbers of postsecondary students with LD/ADHD and concern about the successful academic outcomes of these students.

\subsection{The Present Investigation}

Our goal was to explore the usefulness of the Theory of Planned Behavior model in predicting intention to graduate from postsecondary education in two countries: Canada and Israel. Since of our specific interest is in students with LD/ADHD, we examined results for this group separately in both countries. The Canadian sample was obtained from two junior colleges where students were enrolled in two-year college pre-university diploma/associate's degree programs, while in Israel students were enrolled in a three-year bachelor's program at an open university which uses distance education, and offers students the choice of a blended learning model. Students who choose the blended model combine face-to-face meetings with online courses. Thus, while the samples are very different, findings on predictors of intention to graduate are relevant for both countries and for both students with and without LD/ADHD. We hypothesized that the three TPB model predictors would explain a significant amount of the variability in intention to graduate in all four groups and that all three predictors (i.e., perceived behavioral control, subjective norms, and attitude) would enter the regression equations. In addition, we hypothesized that females would have higher intention to graduate scores than males (e.g., Jorgensen, et al., 2005) and that students with LD/ADHD would 
have lower intention to graduate scores than students without disabilities (e.g., Wagner, Newman, Cameto, Garza, \& Levine., 2005; Weyandt et al., 2013).

\section{Method}

\subsection{Ethics}

The research protocol was approved by Dawson College's Research Ethics Board and by the Ethics Committee of the Open University of Israel.

\subsection{Measures}

Demographic questions. These included gender, age, and number of semesters/courses completed in the student's current school.

Disability self-definition. Participants were asked to self-identify as many of the following disabilities as applied to them: visual impairment not adequately corrected by glasses or contact lenses, Deaf or hard of hearing, LD/ADHD, mobility impairment, chronic medical / health problem, mental illness, autism spectrum disorder, other disability/impairment. Only data from students self-identifying as having LD/ADHD are analyzed in this investigation.

Theory of Planned Behavior Postsecondary Graduation Questionnaire. A one page measure with four subscales was developed by Fichten, et al. (2014). These were adapted from Davis, Ajzen, Saunders, and Williams (2002). Validation and reliability data are available in Fichten et al. (2014, 2015). For the present investigation we made minor changes to the wording of the attitude subscale to facilitate scoring (i.e., we changed the -3 to +3 scale to a 6 point Likert-type scale). We include the English version in Table 1. All subscales use 6-point scaling. Intention to Graduate (e.g., All things considered, it is possible that I might not complete my program of study), uses Likert scaling (Strongly Disagree to Strongly Agree). Likert scaling is also used to evaluate Perceived Behavioral Control over graduation (e.g., It is mostly up to me whether or not I complete my program of study), and Subjective Norms related to graduation (e.g., Most people who are important to me think that I should complete my program of study). Attitude toward graduation is rated on a 6-point Likert-type semantic differential scale (e.g., $1=$ very punishing, $2=$ somewhat punishing, 3 = slightly punishing, $4=$ slightly rewarding, $5=$ somewhat rewarding, $6=$ very rewarding). Scoring of certain items is reversed, so that 1 is the least favorable and 6 is the most favorable score. The mean of each subscale is used for scoring. Attitude, Subjective Norms and Perceived Behavioral Control means can be summed for a Total TPB score. Higher scores indicate more favorable views about graduation. 
Table 1. Theory of Planned Behavior Postsecondary Graduation Questionnaire

For each statement below, rate your level of agreement using the following scale:

1- Strongly disagree

2- Moderately disagree

3- Slightly disagree

4- Slightly agree

5- Moderately agree

6- Strongly agree

\section{Intention (predicted variable)}

- I intend to complete my program of studies.

- I will try to complete my program of studies.

- I expect to complete my program of studies.

- I am determined to complete my program of studies.

- $\quad{ }^{1}$ All things considered, it is possible that I might not complete my program of study

\section{Subjective Norms}

- Most people who are important to me think that I should complete my program of study.

- Most people who are important to me would be disappointed if I did not complete my program of study.

- Most people who are important to me expect me to complete my program of study.

\section{Perceived Behavioral Control}

- I have complete control over completing my program of study.

- I can overcome any obstacles or problems that could prevent me from completing my program of study if I want to.

- It is mostly up to me whether or not I complete my program of study.

- $\quad{ }^{1}$ For me to complete my program of study will be:

1- Very easy

2- Somewhat easy

3- Slightly easy

4- Slightly difficult

5- Somewhat difficult

6- Very difficult

\section{Attitude}

Answer the following questions about how you view completing your program of study. Completing my program of study will be:

$\begin{array}{lccccccl} & \text { Very } & \text { Somewhat } & \text { Slightly } & \text { Slightly } & \text { Somewhat } & \text { Very } & \\ \text { Rewarding } & 6 & 5 & 4 & 3 & 2 & 1 & \text { Punishing } \\ \text { Useful } & 6 & 5 & 4 & 3 & 2 & 1 & \text { Useless } \\ \text { Bad } & 1 & 2 & 3 & 4 & 5 & 6 & \text { Good } \\ \text { Harmful } & 1 & 2 & 3 & 4 & 5 & 6 & \text { Beneficial } \\ \text { Wise } & 6 & 5 & 4 & 3 & 2 & 1 & \text { Foolish } \\ \text { Unpleasant } & 1 & 2 & 3 & 4 & 5 & 6 & \text { Pleasant } \\ \text { Desirable } & 6 & 5 & 4 & 3 & 2 & 1 & \text { Undesirable } \\ \text { Boring } & 1 & 2 & 3 & 4 & 5 & 6 & \text { Exciting }\end{array}$

Scoring: Average each subscale (i.e., Attitude, Subjective Norms, and Perceived Behavioral Control). Higher means indicate more favorable responses. A Total score may be calculated by summing the three subscale means.

${ }^{1}$ Reverse scores.

\subsection{Participant Characteristics}

There were 845 Canadian students over age 18 who had completed at least seven one-semester courses in the pre-university program of one of two large public junior colleges in Quebec, Canada's second largest province. 
Ninety of these students self-reported LD/ADHD (48 females, 42 males); 755 reported having no disability/impairment (448 females, 307 males). Mean age was $19(\mathrm{SD}=1.53)$.

Israeli participants were 641 students over age 17 who had completed at least 4 academic courses in a bachelor's program at the Open University. One hundred and twenty-one of these students self-reported LD/ADHD (62 females, 59 males) while 520 reported having no disability/impairment (302 females, 218 males). Mean age was 29 (SD = 4.98).

To examine age differences, a 3-way between groups analysis of variance comparison (ANOVA) on age ( 2 gender $\mathrm{x}$ 2 country x 2 disability yes/no) was carried out. This revealed only a significant main effect for country, showing that Israeli students were significantly older than Canadian students, $F(1,1466)=1499.24, p<.001$.

To examine gender distribution in the four samples, Chi-square tests showed no significant differences in gender composition of Israeli and Canadian students without disabilities, $\mathrm{X}^{2}(1,1292)=.20, p=.656$, or students with LD/ADHD, $\mathrm{X}^{2}(1,211)=.09, p=.782$.

\subsection{Sampling Procedures}

In Canada, measures were administered in paper and pencil format to all students enrolled in 56 non-first semester compulsory language of instruction classes in two junior colleges. The response rate was over $98 \%$. In Israel the measures were administered via a Google-docs questionnaire submitted to a random sample of 2650 students who successfully finished four academic courses. The response rate was $40 \%$. For the present investigation, only the responses of those who were enrolled in a bachelor's program were used. Inadvertently, in Israel, only three of the nine TPB Attitude items were administered. Therefore, when comparing Canadian and Israeli data we used this abbreviated version of the subscale. As this may have affected the results, we replicated the analyses using the full 9 item scale for the Canadian sample.

\section{Results}

\subsection{Statistics and Data Analysis}

Since Israeli students were significantly older than Canadian students, we covaried age when using analysis of variance (ANOVA) and included age as predictor in regression equations. Because females typically have better academic outcomes than males (e.g., Jorgensen, et al., 2005), we included gender in all analyses. Xxx

\subsection{Intention to Graduate: Comparisons Among Groups (ANOVAs)}

We evaluated the criterion variable, intention to graduate, among Canadian and Israeli male and female students with and without LD/ADHD in a 3-way between groups ANOVA ( 2 gender x 2 country x 2 disability), with age as a covariate. Results in Table 2 indicate only a significant gender main effect, $F(1,1465)=6.29, p=.012$, with females having higher scores. The country main effect was not significant, and the country $\mathrm{x}$ disability interaction approached significance, $F(1,1465)=2.73, p=.099$. No other significant main effects or interactions were found, although it should be noted that, as in other investigations (e.g., Sutter, 2014), this variable was negatively skewed for all Canadian and Israeli samples.

Because North American data have shown that students with LD/ADHD have worse graduation rates than students with no disability, we examined intention to graduate among Canadian students with and without LD/ADHD in an ANOVA test based on a priori hypothesis. Results show that the gender main effect was significant, $F(1,828)=4.24$, $p=.040$, with females having higher scores than males, as was the disability main effect, $F(1,828)=4.25, p=.040$, showing that Canadian students with LD/ADHD had lower intention to graduate scores than students with no disability. The comparison on Israeli students showed no significant differences. 
Table 2. Comparing Canada and Israel on all elements of the TPB Model

\begin{tabular}{crrrrrr}
\hline & \multicolumn{2}{c}{ Canada } & & \multicolumn{2}{c}{ Israel } \\
\cline { 2 - 2 } & Female & Male & & Female & Male \\
Intention to graduate & & & & & \\
LD/ADHD & & & & & 5.52 \\
Mean & 5.58 & 5.47 & & 5.64 & 5.92 \\
$S D$ & 0.89 & 1.05 & & 0.72 & 59 \\
$N$ & 48 & 42 & & 62 & 5.48 \\
No disability & & & & & 218
\end{tabular}

Perceived behavioral control

LD/ADHD

$\begin{array}{rrrrr}\text { Mean } & 4.99 & 5.00 & 5.01 & 4.83 \\ S D & 0.79 & 0.55 & 0.77 & 1.05 \\ N & 48 & 42 & 62 & 59\end{array}$

No disability

\begin{tabular}{|c|c|c|c|c|}
\hline Mean & 5.13 & 5.05 & 0.19 & 5.14 \\
\hline$S D$ & 0.59 & 0.71 & 0.80 & 0.72 \\
\hline$N$ & 443 & 300 & 302 & 218 \\
\hline
\end{tabular}

\section{Subjective norms}

LD/ADHD

$\begin{array}{rrrrr}\text { Mean } & 5.42 & 5.21 & 4.57 & 4.52 \\ S D & 0.93 & 1.01 & 1.33 & 1.47 \\ N & 48 & 42 & 62 & 59\end{array}$

No disability

$\begin{array}{rrrrr}\text { Mean } & 5.62 & 5.48 & 4.46 & 4.45 \\ S D & 0.56 & 0.87 & 1.46 & 1.43 \\ N & 443 & 300 & 300 & 218\end{array}$

Attitude

LD/ADHD

$\begin{array}{rrrrr}\text { Mean } & 5.42 & 5.24 & 4.30 & 3.90 \\ S D & 0.74 & 0.85 & 0.61 & 0.71 \\ N & 47 & 42 & 60 & 57\end{array}$

No disability

$\begin{array}{rrrrr}\text { Mean } & 5.56 & 5.37 & 4.02 & 3.87 \\ S D & 0.62 & 0.70 & 0.77 & 0.78 \\ N & 440 & 299 & 283 & 203\end{array}$

\subsection{Predicting Intention to Graduate (Stepwise Regression Analyses)}

To find out about predictors of intention to graduate among Canadian and Israeli students with and without disabilities, we carried out four stepwise regression analyses, with intention to graduate as the predicted variable, and gender, age, and the three TPB predictors (perceived behavioral control over graduation, subjective norms related to graduation, and attitude toward graduation) as independent variables. We did this separately for the Israeli and Canadian samples with and without LD/ADHD.

Results show that age did not enter any of the regression equations. Table 3 shows that gender entered the regression equation as the 4th item, but only for students without disabilities in both the Canadian and Israeli samples. For both 
Canadian and Israeli samples with and without LD/ADHD, the TPB predictors entered the equation, with all three TPB predictors entering the equations for Canadian, $R^{2}=.443$, and Israeli students without disabilities, $R^{2}=.322$, as well as for Canadian students with LD/ADHD, $R^{2}=.595$. For Israeli students with LD/ADHD, only two of the TPB predictors entered the equation: perceived behavioral control and subjective norms, $R^{2}=.528$.

Table 3. Summary of Stepwise Regression Analyses for Behavioral Intention to Graduate

\begin{tabular}{|c|c|c|c|c|}
\hline Variable & $R^{2}$ & $\beta$ & $\Delta F$ & $p$ \\
\hline \multicolumn{5}{|l|}{ Israel } \\
\hline \multicolumn{5}{|l|}{ Students without disabilities } \\
\hline TPB: Perceived Behavioural Control & 0.255 & 0.46 & 165.650 & $<.001$ \\
\hline TPB: Subjective Norms & 0.298 & 0.20 & 29.210 & $<.001$ \\
\hline TPB: Attitude & 0.316 & 0.13 & 12.410 & $<.001$ \\
\hline Gender & 0.322 & 0.08 & 4.850 & $<.05$ \\
\hline \multicolumn{5}{|l|}{ Students with LD/ADHD } \\
\hline TPB: Perceived Behavioural Control & 0.486 & 0.67 & 108.840 & $<.001$ \\
\hline TPB: Subjective Norms & 0.528 & 0.20 & 9.960 & $<.01$ \\
\hline \multicolumn{5}{|l|}{ Canada } \\
\hline \multicolumn{5}{|l|}{ Students without disabilities } \\
\hline TPB: Subjective Norms & 0.314 & 0.44 & 337.980 & $<.001$ \\
\hline TPB: Perceived Behavioural Control & 0.389 & 0.25 & 90.510 & $<.001$ \\
\hline TPB: Attitude & 0.438 & 0.22 & 63.150 & $<.001$ \\
\hline Gender & 0.443 & 0.08 & 7.160 & $<.01$ \\
\hline \multicolumn{5}{|l|}{${ }^{1}$ Students without disabilities - 9 item Attitude } \\
\hline TPB: Subjective Norms & 0.309 & 0.44 & 330.920 & $<.001$ \\
\hline TPB: Attitude & 0.413 & 0.29 & 131.140 & $<.001$ \\
\hline TPB: Perceived Behavioural Control & 0.459 & 0.23 & 61.870 & $<.001$ \\
\hline \multicolumn{5}{|l|}{ Students with LD/ADHD } \\
\hline TPB: Subjective Norms & 0.525 & 0.63 & 96.180 & $<.001$ \\
\hline TPB: Perceived Behavioural Control & 0.573 & 0.21 & 9.710 & $<.01$ \\
\hline TPB: Attitude & 0.595 & 0.15 & 4.660 & $<.01$ \\
\hline \multicolumn{5}{|l|}{${ }^{I}$ Students with LD/ADHD - 9 item Attitude } \\
\hline TPB: Subjective Norms & 0.520 & 0.61 & 96.180 & $<.001$ \\
\hline TPB: Perceived Behavioural Control & 0.563 & 0.21 & 9.710 & $<.01$ \\
\hline TPB: Attitude & 0.592 & 0.19 & 7.140 & $<.01$ \\
\hline
\end{tabular}

Note: $\mathrm{TPB}=$ Theory of Planned Behavior

${ }^{1}$ Based on the 9-item Attitude subscale

Inadvertently, in Israel only 3 of the 9 TPB Attitude items were administered. This may have affected the findings. Therefore, we carried out the Canadian regression analyses including the entire attitude scale. Results are very similar to the analyses with the short attitude subscale - these can be seen in Table 3. The main difference is that gender is no longer a significant predictor for the Canadian students without disabilities.

3.4 Comparing TPB Model Components: ANOVAs

Although there is a great deal of similarity in predicting intention to graduate among the four groups, there are subtle differences based on disability, country, and gender among the TPB model predictors. For example, Table 3 shows a significant disability main effect for perceived behavioral control, $F(1,1469)=9.52, p<.01$, indicating that participants with LD/ADHD felt that they had less control over graduation than those with no disability. In addition, on subjective norms there was a significant country main effect, $\mathrm{F}(1,1464)=69.56, \mathrm{p}<.001$, and a country $\mathrm{x}$ disability interaction, $\mathrm{F}(1,1464)=3.91, \mathrm{p}<.05$, showing that subjective norms were more favorable in Canada than in Israel, especially among Canadians with no disability. As for attitude the results show a significant county, $F(1,1426)=279.37, p<.001$ and gender main effects, $F(1,1426)=19.06, p<.001$, indicating that Canadians had more positive attitudes about graduation than Israelis and that females had more favorable attitudes than males. In addition, 
there was a country $\mathrm{x}$ disability interaction, $\mathrm{F}(1,1426)=6.89, \mathrm{p}<.01$, suggesting that Canadians with no disability and Israelis with LD/ADHD had relatively more favorable attitude toward graduation than students without disabilities.

\section{Discussion}

\subsection{Summary of Findings}

Our findings show that predictions based on the TPB are very robust. For example, despite vast differences between our Canadian and Israeli samples (e.g., on age, junior college vs. open university) and between samples with and without learning disabilities / attention deficit hyperactivity disorder, intention to graduate was related to the TPB predictors for both students with and without LD/ADHD, predicting between 32\% and 59\% of the variability in intention to graduate. Even though women had stronger intentions to graduate than men, a finding similar to that of others (Jorgensen et al., 2009; National Center for Education Statistics, 2010; Mamiseishvili \& Koch, 2011, 2012; O'Neill, Markward, \& French, 2012), gender either failed to enter the regression model or did so only as the last variable, adding very little to the prediction. It is, thus, the TPB predictors (i.e., perceived behavioral control, subjective norms, and attitude) that are most closely related to intention to graduate.

\subsection{Limitations and Future Research}

We need to note that we studied intention to graduate and not actual graduation. In future research it would be desirable to include objective measures, such as actual graduation and drop-out. Yet, actual graduation has also been studied in both cross-sectional (Fichten et al., 2014) and longitudinal (Fichten et al., 2015) studies, and the data suggest that the TPB model predictors do a well at predicting both intention to graduate as well as actual graduation. A variety of additional limitations of our investigation need to be highlighted: different levels of study in Canada and Israel, large age difference, paper and pencil vs. online administration of the measure, and self-definition of LD/ADHD. Moreover, we did not distinguish among students with specific learning disabilities and those with attention deficit hyperactivity disorder. Even though there is substantial comorbidity between these disorders, it is important to study these samples separately.

In future investigations, research should be carried out at different schools where all students complete measures perhaps in the context of institutional research - and thus, the results are not affected by volunteer or self-selection effects. We also suggest using the Theory Of Planned Behavior Postsecondary Graduation Questionnaire in longitudinal studies of actual academic persistence (staying in school from one semester to the next) as well as graduation and drop-out rates in random samples of students in different fields of study and different programs (e.g., college diploma, bachelor degree, graduate studies, etc.), and fields of study (e.g., sciences, arts, etc.). In addition, the timing of questionnaire administration needs further study since it is possible that students are more optimistic at the start of the academic term than in the middle, and that students close to completing their studies may be more likely to intend to graduate than those just starting out. As well, research needs to evaluate the extent to which the model can be generalized to different populations of students, including those from different ethnic backgrounds, nationalities and socio-economic levels.

\subsection{Practical Uses of the Theory of Planned Behavior Postsecondary Graduation Questionnaire}

It should be noted that all scales of the Theory Of Planned Behavior Postsecondary Graduation Questionnaire fit on a single page (available in Table 1), that it is easily converted for web administration, that it is free, and that it takes only about 5 minutes to administer. Scoring is simple - it only requires computing the TPB subscale averages. Given our findings, the questionnaire is likely to be valid for diverse postsecondary samples and countries, and it can be used as a quick, inexpensive way to predict graduation intentions.

School-wide interventions designed to improve graduation can be directed at one or more of its three predictors: attitude, subjective norms, and perceptions of behavioral control. For example, communications in the form of information pamphlets, quick-facts emails, workshops and key information which is integrated into academic programs about the impact of graduation on salary, on the likelihood of finding a satisfying job, and on not "feeling left behind" can be used to improve attitude toward graduation. Informing students about the favorable views of their peers and of important sources of influence, such as media stars, sports figures, etc. about graduation could increase subjective norms. Ajzen (2002) notes that perceived behavioral control is composed of two components: self-efficacy beliefs (i.e., belief that once can successfully carry out a task) and control expectations (i.e., perception of control over diverse challenges of college life, such as registration, studying, obtaining needed financial resources, and finding housing). There is a substantial literature on ways to enhance academic self-efficacy (e.g., Schunk \& Ertmer, 1999; Komarraju \& Nadler, 2013) as well as control expectations (e.g., Stupnisky, Renaud, Daniels, Haynes, \& Perry, 2008). Certainly, enhancing these in the entire student body can help promote perceived behavioral control. For example, 
information on financial aid, study skills and management of exam anxiety, etc. can help improve perceived behavioral control. In particular, males, who have weaker intentions to graduate, should be targeted vigorously. In Canada, students with LD/ADHD need to receive special attention as well. Higher education institutes can offer guidance or workshops to encourage students with and without disabilities to continue their efforts and support them in finishing their studies.

\section{Acknowledgements}

This research was funded by the Fonds de recherche du Québec - Société et culture (FRQSC) and the Ministère de l’Éducation, du Loisir et du Sport (MELS). We are grateful to Evelyne Marcil for her helpful comments.

\section{References}

Advokat, C., Lane, S. M., \& Luo, C. (2011). College students with and without ADHD: Comparison of self-report of medication usage, study habits, and academic achievement. Journal of Attention Disorders, 15, 656-666. http://dx.doi.org/10.1177/1087054710371168

Ajzen, I. (1991). The Theory of Planned Behavior. Organizational Behavior and Human Decision Processes, 50, 179-211. http://dx.doi.org/10.1016/0749-5978(91)90020-T

Ajzen, I. (2002). Perceived behavioral control, self-efficacy, locus of control, and the theory of planned behavior. Journal of Applied Social Psychology, 32(4), 665-683. http://dx.doi.org/10.1111/j.1559-1816.2002.tb00236.x

Ajzen, I. (2012). The theory of planned behavior. In P. A. M. Lange, A. W. Kruglanski, \& E. T. Higgins (Eds.), Handbook of theories of social psychology, 1, 438-459. London, UK: Sage. http://dx.doi.org/10.4135/9781446249215.n22

Ajzen, I. (undated a). Definition of intention. Retrieved from http://people.umass.edu/aizen/int.html

Ajzen, I. (undated b). Behavioral interventions based on the theory of planned behavior. Retrieved from http://people.umass.edu/aizen/pdf/tpb.intervention.pdf

American College Testing Program. (2013). National collegiate retention and persistence to degree rates: 2013 Retention/completion summary tables. Retrieved from ACT Policy Publications website, http://www.act.org/research/policymakers/pdf/retain_2013.pdf

Armitage, C. J, \& Conner, M. (2001). Efficacy of the theory of planned behavior: A meta-analytic review. British Journal of Social Psychology, 40(4), 471-499. http://dx.doi.org/10.1348/014466601164939

Bean, J. P. (1982). Student attrition, intentions and confidence: Interactions effects in a path model. Research in Higher Education, 17(4), 291-319. http://dx.doi.org/10.1007/BF00977899

Chen, R. (2012). Institutional characteristics and college student dropout risks: A multilevel event history analysis. Research in Higher Education, 53(5), 487-505. http://dx.doi.org/10.1007/s11162-011-9241-4

Davis, L. E., Ajzen, I., Saunders, J., \& Williams, T. (2002). The decision of African American students to complete high school: An application of the theory of planned behavior. Journal of Educational Psychology, 94(4), 810-819. http://dx.doi.org/10.1037//0022-0663.94.4.810

DuPaul, G. J., Gormley, M. J., \& Laracy, S. D. (2013). Comorbidity of LD and ADHD: implications of DSM-5 for assessment and treatment. Journal of Learning Disabilities, 46(1), 43. http://dx.doi.org/10.1177/0022219412464351

Fichten, C., Amsel, R., Jorgensen, M., Nguyen, M.N., Budd, J., Havel, A., King, L., Jorgensen, S., \& Asuncion, J. (2015). Theory of Planned Behavior: Sensitivity and specificity in predicting graduation and drop-out among college and university students. Manuscript submitted for publication.

Fichten, C. S., Asuncion, J. V., Wolforth, J., Barile, M., Budd, J., Martiniello, N., \& Amsel, R. (2012). Information and communication technology related needs of college and university students with disabilities. Research in Learning Technology, 20, 323-344. http://dx.doi.org/10.3402/rlt.v20i0.18646

Fichten, C. S., Nguyen, M. N., Amsel, R., Jorgensen, S., Budd, J., Jorgensen, M., Asuncion, J., \& Barile, M. (2014). How well does the Theory of Planned Behavior predict graduation among college and university students with disabilities? Social Psychology of Education, 17(4), 657-685. http://dx.doi.org/10.1007/s11218-014-9272-8

Getzel, E. E., \& Thoma, C. A. (2008). Experiences of college students with disabilities and the importance of self-determination in higher education settings. Career Development for Exceptional Individuals, 31(2), 77-84. http://dx.doi.org/10.1177/0885728808317658 
Heiman, T., \& Precel, K. (2003). Students with learning disabilities in higher education: Academic strategies profile. Journal of Learning Disabilities, 36 (3), 248-258. http://dx.doi.org/10.1177/002221940303600304

Heller, M. L., \& Cassady, J. C. (2015). Predicting community college and university student success: A test of the triadic reciprocal model for two populations. Journal of College Student Retention. Advance online publication. http://dx.doi.org/10.1177/1521025115611130

Hudy, G. T. (2007). An analysis of motivational factors related to academic success and persistence for university students (Doctoral dissertation). Available from Dissertation Abstracts International Section A: Humanities and Social Sciences, 67, 11-A. (UMI No. 3240170).

Jorgensen, S., Ferraro, V., Fichten, C. S., \& Havel, A. (2009). Predicting the at risk status of college students: Males and students with disabilities. Final report presented to Programme d'aide à la recherche sur l'enseignement et l'apprentissage (PAREA). Retrieved from ERIC database. (ED505871)

Jorgensen, S., Fichten, C. S., \& Havel, A. (2008, October). Predicting student attrition - How helpful are surveys? Presentation at the Canadian Institutional Research and Planning Association (CIRPA) annual convention, Quebec. $\quad$ Retrieved http://www.adaptech.org/sites/default/files/abPredictingStudentAttritionHowHelpful.pdf

Jorgensen, S., Fichten, C. S., Havel, A., Lamb, D., James, C., \& Barile, M. (2005). Academic performance of college students with and without disabilities: An archival study. Canadian Journal of Counselling, 39(2), 101-117. Retrieved from http://cjc-rcc.ucalgary.ca/cjc/index.php/rcc

Komarraju, M., \& Nadler, D. (2013). Self-efficacy and academic achievement: Why do implicit beliefs, goals, and effort regulation matter? Learning and Individual Differences, 25, 67-72. http://dx.doi.org/10.1016/j.lindif.2013.01.005

Lang, R., Ramdoss, S., Sigafoos,J., Green, V.A., van der Meer, L., Tostanoski, A., Lee, A., \& O’Reilly, M.F. (2014). Assistive technology for postsecondary students with disabilities. In G. E. Lancioni and N. N. Singh (Eds). Assistive technologies for people with diverse abilities (pp 53-76). New York: Springer Science+Business Media. http://dx.doi.org/10.1007/978-1-4899-8029-8_3

Lombardi, A. R., Murray, C., \& Gerdes, H. (2012). Academic performance of first-generation college students with disabilities. Journal of College Student Development, 53(6), 811-826. http://dx.doi.org/10.1353/csd.2012.0082

Luke, C., Redekop, F. \& Burgin, C. (2015). Psychological factors in community college student retention. Community College Journal of Research and Practice, 39(3), 222-234. http://dx.doi.org/10.1080/10668926.2013.803940

Mamiseishvili, K., \& Koch, L. C. (2011). First-to-second-year persistence of students with disabilities in postsecondary institutions in the United States. Rehabilitation Counseling Bulletin, 54(2), 93-105. http://dx.doi.org/10.1177/0034355210382580

Mamiseishvili, K., \& Koch, L. C. (2012). Students with disabilities at 2-year institutions in the United States: Factors related to success. Community College Review, 40(4), 320-339. http://dx.doi.org/10.1177/0091552112456281

Ministry of Training, Colleges \& Universities. (2012, May). Update on students with disabilities. PowerPoint presentation at Postsecondary Education Division, Ontario.

National Center for Education Statistics. (2010). Number and percentage distribution of students enrolled in postsecondary institutions, by level, disability status, and selected student and characteristics: 2003-04 and 2007-08. Washington, DC: National Center for Education Statistics. Retrieved from http://nces.ed.gov/programs/digest/d10/tables/dt10_240.asp

McCloy, U. \& DeClou, L. (2013, February 21). Disability in Ontario: Postsecondary education participation rates, student experience and labour market outcomes. Higher Education Quality Council of Ontario. Retrieved from http://heqco.ca/SiteCollectionDocuments/At\%20Issue\%20-\%20Disability\%20in\%20ON_ENG.pdf

McEachan, R.R.C., Conner, M., Taylor, N., \& Lawton, R.J. (2011). Prospective prediction of health-related behaviors with the Theory of Planned Behavior: A meta-analysis. Health Psychology Review, 5, 97-144. http://dx.doi.org/10.1080/17437199.2010.521684

NCES (National Center for education Statistics) (2011). Students with disabilities at degree-granting postsecondary institutions: First look. Washington, DC: US Department of Education. Retrieved from http://oeraccess.merlot.org/_media/documents/Students\%20with\%20Disabilities.pdf 
OECD (2012, 2013). Education at a glance. Retrieved from http://www.oecd.org/edu/highlights.pdf and from http://www.oecd.org/edu/Israel_EAG2013\%20Country\%20Note.pdf

O'Neill, L. N. P., Markward, M. J., \& French, J. P. (2012). Predictors of graduation among college students with disabilities. Journal of Postsecondary Education and Disability, 25(1), 21-36. Retrieved from http://www.ahead.org/publications/jped

Parker, D. R., \& Banerjee, M. (2007). Leveling the digital playing field: Assessing the learning technology needs of college-bound students with LD and/or ADHD. Assessment for Effective Intervention, 33, 5-14. http://dx.doi.org/10.1177/15345084070330010201

Raue, K., \& Lewis, L. (2011). Students with disabilities at degree-granting postsecondary institutions (NCES Publication No. 2011018). Retrieved from National Center for Education Statistics website: http://nces.ed.gov/pubs2011/2011018.pdf

Schunk, D. H., \& Ertmer, P. A. (1999). Self-regulatory processes during computer skill acquisition: Goal and self-evaluative influences. Journal of Educational Psychology, 91(2), 251-260. http://dx.doi.org/10.1037/0022-0663.91.2.251

Shaienks, D., Gluszynski, T., \& Bayard, J. (2008, November). Postsecondary education - Participation and dropping out: Differences across university, college and other types of postsecondary institutions. Statistics Canada, Catalogue no. 81-595-M, no. $070 . \quad$ Retrieved from http://www.statcan.gc.ca/pub/81-595-m/81-595-m2008070-eng.pdf

Snyder, T. D. \& Dillow, S. A. (2012). Digest of education statistics 2011. NCES 2012-001. Washington, DC: National Center for Education Statistics, Institute of Education Sciences, U.S. Department of Education. Retrieved March 11, 2013, from http://nces.ed.gov/pubs2012/2012001.pdf

Strom, R. E., \& Savage, M. W. (2014). Assessing the relationship between perceived support from close others, goal commitment, and persistence decisions at the college level. Journal of College Student Development, 55(6), 531-547. http://dx.doi.org/10.1353/csd.2014.0064

Stupnisky, R. H., Renaud, R. D., Daniels, L. M., Haynes, T. L., \& Perry, R. P. (2008). The interrelation of first-year college students' critical thinking disposition, perceived academic control, and academic achievement. Research in Higher Education, 49(6), 513-530. http://dx.doi.org/10.1007/s11162-008-9093-8

Sutter, N. (2014). Predicting college students' intention to graduate: A test of the theory of planned behavior (Doctoral dissertation, Ball State University. Retrieved from http://cardinalscholar.bsu.edu/bitstream/handle/123456789/198445/SutterN_2014-3_BODY.pdf?sequence=1

The Open University: (2013, 2014). The President Report. Retrieved from http://www-e.openu.ac.il/presidents-office/report2013E/index.html from http://www-e.openu.ac.il/presidents-office/report2014E/26-27.pdf

Thomas, D. (2014). Factors that influence college completion intention of undergraduate students. The Asia-Pacific Education Researcher, 23(2), 225-235. http://dx.doi.org/10.1007/s40299-013-0099-4

Tinto, V. (1975). Dropout from higher education: A theoretical synthesis of recent research. Review of Educational Research, 45(1), 89-125. http://dx.doi.org/10.3102/00346543045001089

Wagner, M., Newman, L., Cameto, R., Garza, N., \& Levine, P. (2005). After high school: A first

look at the postschool experiences of youth with disabilities: A report from the National Longitudinal Transition Study-2 (NLTS2). U.S. Department of Education. Retrieved from http://www.nlts2.org/reports/2005_04/nlts2_report_2005_04_execsum.pdf

Wessel, R. O., Jones, J. A., Markle, L., \& Westfall, K. (2009). Retention and graduation of students with disabilities: Facilitating student success. Journal of Postsecondary Education and Disability, 21(3), 116-125. Retrieved from http://www.ahead.org/publications/jped

Weyandt, L., DuPaul, G. J., Verdi, G., Rossi, J. S., Swentosky, A. J., Vilardo, B. S., O’Dell, S.M., \& Carson, K. S. (2013). The performance of college students with and without ADHD: Neuropsychological, academic, and psychosocial functioning. Journal of Psychopathology and Behavioral Assessment, 35(4), 421-435. http://dx.doi.org/10.1007/s10862-013-9351-8 